\title{
変形形状制御のための編み地のモデリング
}

\author{
和田 隆 広* 平井慎 一* 平 野 達 也* 川 村 貞 夫*
}

\section{Modeling of Knitted Fabrics for Their Deformation Control}

\author{
Takahiro Wada*, Shinichi Hirai*, Tatsuya Hirano* and Sadao Kawamura*
}

\begin{abstract}
A new approach to the modeling of plain knitted fabrics is presented for their deformation control. There exist many manipulative operations that deal with deformable soft objects such as clothes, papers, wires, and so on. Most of these operations are still done manually by skilled workers and automatic control of these operations is required. Especially, automatic handling of knitted fabrics is desired in garment industries. Automatic handling of knitted fabrics is, however, difficult to be performed by machines since the knitted fabrics can be easily deformed and extended during the handling operations. It is needed to control the deformation of knitted fabrics during the operations. A mathematical model of the fabrics will enable us to derive efficient strategy to control their deformation. Therefore, a mathematical model of the fabrics is essential for the deformation control.

In this paper, we present a mathematical model of plain knitted fabrics based on their loop structure. Plain knitted fabrics consist of knitted loops and shapes of the fabric can be derived by computing the deformation of the loops involved in a fabric. It is, however, difficult and time consuming to calculate all deformed shapes of a huge number of knitted loops involved in a fabric. We thus propose a new procedure called representative loop method so that the deformation can be computed in an appropriate time. In the representative loop method, some representative loops are selected in advance in order to compute the deformed shapes of all other loops by interpolating those of the representative loops. The validity of the proposed method is then demonstrated through the comparison of the calculated shapes and the real images of deformed knitted fabrics.
\end{abstract}

Key Words: Deformable Objects, Knitted Fabrics, Modeling, Deformation Control, Cloth

\section{1.はじめに}

生産現場には，布地，紙，ゴム，革製品など，柔らかく変形 しやすい物体を扱う作業が数多く見受けられる。これらの作業 の多くは，現在でも人手に頼る部分が多く，ロボットなどの機 械システムによる作業の自動化が望まれている。このように柔 らかく変形しやすい物体を操作する際には，ロボットなどの機 械システム側だけの研究では不十分であり，対象物体の機械的 性質を考慮した作業戦略を立てる必要がある。すなわち, 柔軟 物のハンドリングを自動化するためには，対象物体の力学的性 質に関する解析やモデリングが重要となる.

本研究では, 柔軟变形対象物体のなかで, 特にニットを対象 とする。ニットは，伸縮性に富む布地であり，複雑な変形特性 を示す。そのために，自動生産が遅れている対象である。ニッ 卜製品生産の自動化のためには，ニットの変形特性を考慮に入 れて，適切な機械システムを設計・製作する必要がある。さら に，生産工程において布地の変形形状を制御する必要があるた

原稿受付 1997 年 8 月 1 日

*立命館大学理工学部

${ }^{*}$ Faculty of Science and Engineering, Ritsumeikan University
め，伸縮変形を考慮に入れた機械システムの制御手法について も検討を要する。したがって，ニット製品の自動生産システム を構成するためには，ニットの変形の数理モデルが重要となる. 布地のモデリングに関して, いくつかの研究が成されている. Leaf は, 無負荷状態での平編み地の形状を解析している [1]. こ のモデルでは, 変形形状を記述できないため, ニットの変形形 状制御には適用できない.川端らは, 平編み地の 2 軸伸張特性 を表現するためのモデルを提案している [2].このモデルでは， 布全体に作用する力と布の変形の関係を扱っている。しかしな がら, 編み目に関しては, その特性をモデルの計算に導入して いるのみで, 編み目の変形形状については考慮していない。ま た，このモデルでは, 縦・横方向の均一な変形のみを扱ってお り, 斜め方向の変形など, 一般的な変形を扱っていない。ニッ 卜製品の生産においては, ニットの変形形状が必ずしも一様で はない. したがって, 川端らのモデルは, ニットの変形形状制 御には十分ではない. また，コンピュータグラフィクスの分野 でも，布地の変形形状を表すモデルが提案されている．Weil は, 布地の曲げ変形をモデル化している [3].このモデルでは, 操作点の位置は記述できるが, その間の布地の形状は懸垂線に よって近似的に決定されるため, その部分の正確な形状, 位置 
は予測できない. Terzopoulos らは, 連続体の弾性変形をコン ピュータグラフィクスで表現するための, 数理モデルを提案し ている.このモデルでは, ニットの編み構造のような複雑な構 造の挙動を定式化するのには不適切であり, その手順について も触れられていない。 さらに，位置決め作業の解析で重要であ ると考えられる幾何学的拘束を表現する手法についても, 言及 されていない。ニット製品の生産においては, 変形形状の制御 のみならず編み目の位置の制御が必要になる工程がある.上述 のモデルでは, 変形形状における編み目の位置を表現すること ができない。したがって，編み目を考慮に入れたニットのモデ リング技法が望まれる。

本論文では，ニットの变形形状制御のために，編み目の形状 を考慮に入れた, 編み地の新しいモデリング手法を提案する. このモデルは編み地の変形を, 編み目形状の変形を用いて表現 する点に特徴がある。ニットを構成するすべての編み目形状の 変形を計算することにより, 編み地の変形を求めることができ る.しかしながら, 編み地は多くの編み目から構成されている ため,すべての編み目の変形形状を計算することは困難である. そこで，代表的な編み目の形状を用いて他の編み目の形状を記 述することにより，計算時間を削減する手法を提案する。この 手法を本論文では，代表編み目法と呼ぶ.

本論文の構成を以下に示す，第 2 節では，まずニットの編み 組織について説明する。また, ニット製品の製造工程を分析し, 編み目の位置決めが重要であることを示す，第 3 節では，ニッ トの変形形状を表現する数理モデルを提案する。第 4 節では, 代表編み目法に基づいて，モデルの計算時間を削減する二つの 手法を提案する。またこれらの手法を用いた計算例を示す. 第 5 節では, 実際の布地を変形させ, 提案したモデルの計算結 果と比較し，提案するモデリング技法の有効性を検証する.

\section{2. ニット製品の製造工程の分析}

\section{1 ニットの編み組織}

本節では、ニットの編み組織について説明する。編み地は 1 本または数本の系から構成されている．Fig. 1 に示す編み組 織は，平編みと呼ばれ，もっとも基本的な編み組織の一つであ る.Fig. 1(a)，(b) はそれぞれ，編み地の表，裏を表す。本論 文では,この平編み地を対象とする. 図に示すとおり, 編み目 の行方向, および列方向はそれぞれ, course, waleと呼ばれて いる。斜線の入った部分は編み目（loop）と呼ばれる.

\section{2 ニットの編み目の位置決め作業}

ニット製品の製造工程では, 編み目形状と編み目の位置決め が非常に重要な作業である。例えば，ニットを縫製する手法の 一つに，リンキング縫製がある [5]. リンキングによって縫製 された製品は, ニットの伸縮性等の特徵が活かされており, 高 級品とされている. Fig. 2 にリンキングの概念図を示す. 図に 示すように，リンキング縫製では，まず，対応する編み目をす ベて一対一に位置決めする，その後，位置決めされた編み目に ミシン針を挿入し，縫合する。このような位置決め作業では, 編み目の位置および形状が重要であるため, 布地の変形を表 す数理モデルに, 編み目の形状を表現する能力が要求される. Fig. 3 に示すように, 位置決め作業では, 編み地を変形させる

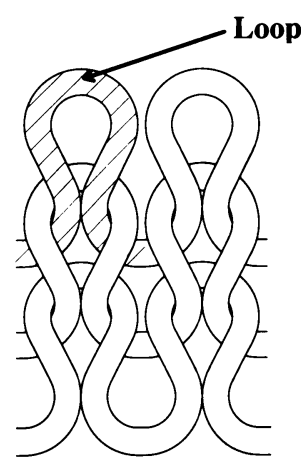

(a) Face side

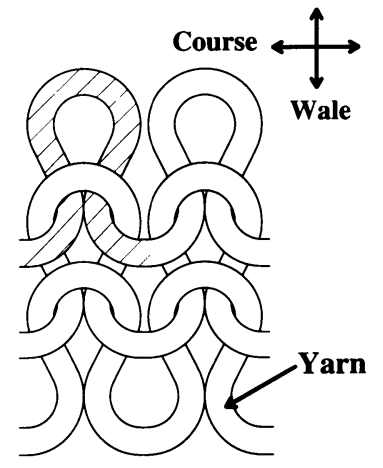

(b) Reverse side
Fig. 1 Loop structure of plain knitted fabrics

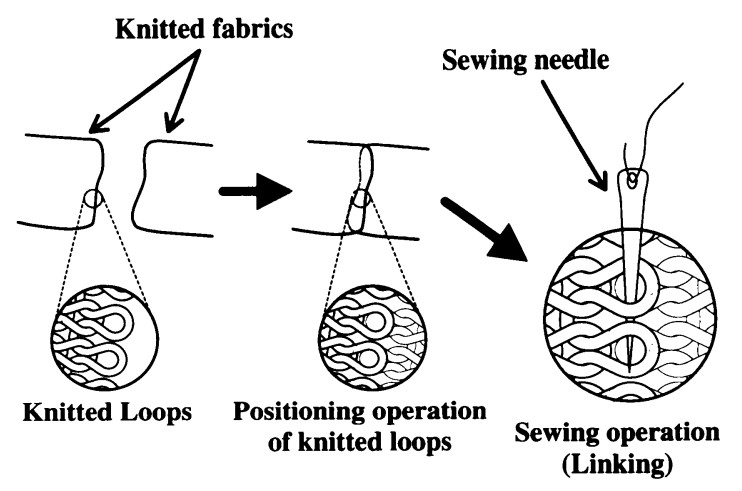

Fig. 2 Linking of knitted fabrics

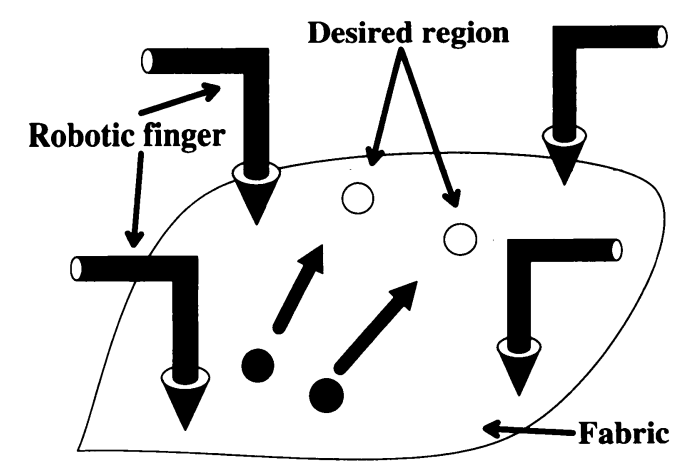

Fig. 3 Positioning operations of knitted fabrics

ことで, 編み地の上のいくつかの編み目を目標の領域へ移動さ せる，通常，作業者は，これらの作業を次のように簡単に行っ ている。まず, 布の曲げ変形を拘束するために, 指を用いて布 を引っ張る、次に, 編み目の形状に注意しながら, 指の位置を 制御することで，目的とする位置決め作業を実現する。このよ うに作業者は，優れた作業戦略を用いて，位置決めを効果的に 行っている。このような位置決め作業を, 機械システムで実現 するためには，1）編み地の上での多点位置制御メカニズム，な らびに2）位置決めのための制御戦略，が必要であると考えら れる。布の変形を拘束し, かつ布地上の編み目を位置決めする ためには，人の指に代わる多点位置制御機構が必要である。ま 


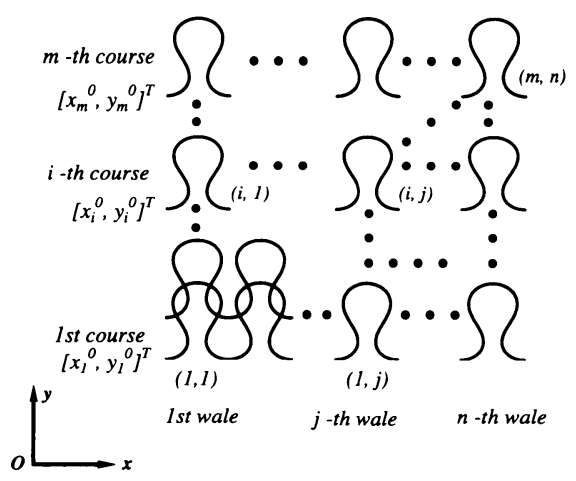

Fig. 4 Coordinate systems of knitted loops

た，位置決め作業を行うためには，編み目の位置と形状を効果 的に制御するための戦略が必要である。したがって, ニットの 自動生産のためには, 編み目の位置と形状の両方を表現できる 数理モデルが必要となる.

\section{3. 編み地のモデリング}

\section{1 変形形状の表現}

本節では，平編み地の数理モデルを提案する。ここで, 編み 地が編み組織を持つことに注意する，そこで，編み地の变形を， 編み目の変形によって記述することを考える.

本論文では，布が二次元平面内でのみ変形を行うと仮定する。 Fig. 4 に示すように，編み目の中心線を抜き出す，布が変形す る平面に固定された空間座標を, $O-x y$ とする. 布は, course, wale 方向にそれぞれ, $m, n$ 個の編み目を持つとする．図に示 すように，第 $i$ course, 第 $j$ wale の編み目を，第 $(i, j)$ 編み 目 と定義する. 図中の, $x_{i}^{0}$ と $y_{i}^{0}$ は第 $(i, 1)$ 編み目の左端の点 の空間座標値である．個々の編み目の形状をモデリングするた めに, Fig. 5 に示すように, 第 $(i, j)$ 編み目を取り出す。編み 目の左端から中心線に沿って測った距離を $s$ と定義する。ここ で, 一つの編み目の系の長さが変化しないと仮定し, その長さ を $L$ で表す．第 $(i, j)$ 編み目において, $x$ 軸から測った座標 $s$ における接線の角度を $\theta_{i, j}(s)$ で表す。編み目の変形形状は, この $\theta_{i, j}(s)$ によって決定される. 第 $(i, j)$ 編み目の座標 $s$ に おける空間座標 $x_{i, j}(s)$ および $y_{i, j}(s)$ は, 次式で表現される.

$$
\begin{aligned}
& {\left[\begin{array}{l}
x_{i, j}(s) \\
y_{i, j}(s)
\end{array}\right]=} \\
& {\left[\begin{array}{c}
s \\
\int_{0}^{s} \cos \theta_{i, j}(s) d s+\sum_{\substack{k=1 \\
j-1}}^{j-1} \int_{0}^{L} \cos \theta_{i, k}(s) d s+x_{i}^{0} \\
\int_{0}^{s} \sin \theta_{i, j}(s) d s+\sum_{k=1}^{L} \int_{0} \sin \theta_{i, k}(s) d s+y_{i}^{0}
\end{array}\right]}
\end{aligned}
$$

\section{2 絡み部のモデリング}

ニットは, 1 本もしくは数本の系が絡まり合うことで構成さ れているため, その絡まり部分における系の挙動が布地の変形 形状に影響する，そこで，系の絡まり部分の性質を，次のよう にモデリングする．Fig. 6 に示すように，第 $(i, j)$ 編み目と 第 $(i-1, j)$ 編み目の絡み部分に着目する. 布地が変形すると,

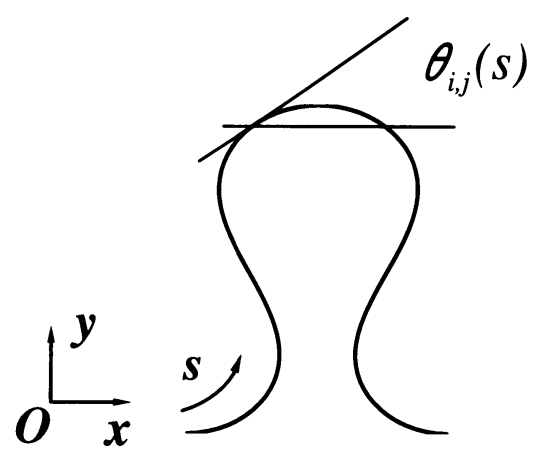

Fig. 5 Description of deformation of $(i, j)$-th loop

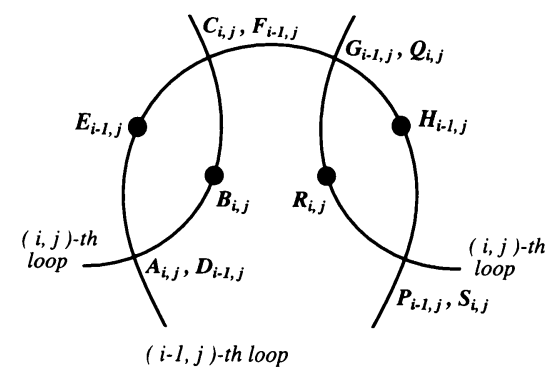

Fig. 6 Intertwined part of knitted loops

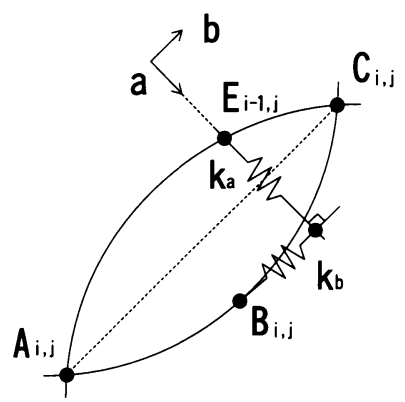

Fig. 7 Spring model of intertwined part

この二つの編み目は互いに干涉し合う。この干渉により，から まり部分の糸は半径方向へ変形する。この現象は, 二つの編み 目の系の半径方向のバネによってモデル化できると仮定する. また, 絡まり部分の系の接線方向には, 摩擦力が㗢く，摩擦力 は, 2 本の系の接触部分において, 糸が接線方向へ滑るのを妨 げている，そこでこの摩擦力を, 絡み部の系の接線方向のバネ によってモデル化できると仮定する，結果として，編み目間の 干渉は, Fig. 7 に示すような, 糸の半径方向と接線方向の 2 本 のバネでモデル化される。ここで, $A_{i, j}, D_{i-1, j}, C_{i, j}, F_{i-1, j}$, $Q_{i, j}, G_{i-1, j}, S_{i, j}$, および $P_{i, j}$ は第 $(i-1, j),(i, j)$ 編み目の 交点である. 点 $A_{i, j}$ および $D_{i-1, j}$ に対応する $(i, j),(i-1, j)$ 編み目における左端からの距離を，それぞれ， $s_{A i, j}, s_{D i-1, j}$ とおく. 点 $C_{i, j}$ および $F_{i-1, j}$ に対応する $(i, j),(i-1, j)$ 編み 目における左端からの距離を，それぞれ， $s_{C i, j}$ および $s_{F i-1, j}$ とおく. 次に, 距離 $s_{B i, j}, s_{E i-1, j}, s_{H i-1, j}, s_{R i, j}$ を以下の ように定め, 対応する編み目上の点を, 眓に示すように, $B_{i, j}$, 


$$
\begin{aligned}
E_{i-1, j}, H_{i-1, j}, R_{i, j} & \text { とする. } \\
s_{B i, j} & =\frac{1}{2}\left(s_{A i, j}+s_{C i, j}\right) \\
s_{E i-1, j} & =\frac{1}{2}\left(s_{D i-1, j}+s_{F i-1, j}\right) \\
s_{H i-1, j} & =\frac{1}{2}\left(s_{G i-1, j}+s_{P i-1, j}\right) \\
s_{R i, j} & =\frac{1}{2}\left(s_{Q i, j}+s_{S i, j}\right)
\end{aligned}
$$

点 $A_{i, j}, B_{i, j}, C_{i, j}, E_{i, j}$ の初期位置を, $A_{i, j}^{0}, B_{i, j}^{0}, C_{i, j}^{0}, E_{i, j}^{0}$ とする. 図に示すように, $A_{i, j}^{0} \vec{C}_{i, j}^{0}$ に平行な単位べクトルを $\boldsymbol{b}$, $\boldsymbol{b}$ に直交する単位ベクトルを $\boldsymbol{a}$ とおく. ベクトル $\boldsymbol{a}, \boldsymbol{b}$ は, 初 期形状によって決まり, 編み目が変形しても变化しないと仮定 する. ベクトル $\boldsymbol{a}, \boldsymbol{b}$ 方向のバネ係数をそれぞれ, $k_{a}, k_{b}$ とお く.また, $K=\operatorname{diag}\left(k_{a}, k_{b}\right)$ とする. 系の半径方向, 接線方向 の 2 本のバネのポテンシャルエネルギー $U_{i, j}^{A C}$ は, 次式で与え られる。

$$
U_{i, j}^{A C}=\frac{1}{2} \Delta \boldsymbol{z}_{i, j}^{T} K \Delta \boldsymbol{z}_{i, j}
$$

ここで, $\Delta \boldsymbol{z}_{i, j}$ は, 絡まり部べクトルの変化分の $\boldsymbol{a}$ 方向成分と $\boldsymbol{b}$ 方向成分からなるなるべクトルである.すなわち，

$$
\begin{aligned}
\Delta \boldsymbol{z}_{i, j}= & {\left[\left(B_{i, j} \vec{E}_{i-1, j}-B_{i, j}^{0} \vec{E}_{i-1, j}^{0}\right)^{T} \boldsymbol{a}\right.} \\
& \left.\left(B_{i, j} \vec{E}_{i-1, j}-B_{i, j}^{0} \vec{E}_{i-1, j}^{0}\right)^{T} \boldsymbol{b}\right]^{T}
\end{aligned}
$$

同様に, 点 $Q_{i, j}$ および $S_{i, j}$ における二つのバネのポテンシャル エネルギー $U_{i, j}^{Q S}$ が定められる。第 $(i, j)$ 編み目 と第 $(i-1, j)$ 編み目の干涉によるバネのポテンシャルエネルギー $U_{i, j}^{\text {spring }}$ は, 次式で与えられる。

$$
U_{i, j}^{s p r i n g}=U_{i, j}^{A C}+U_{i, j}^{Q S}
$$

全編み目の絡まり部分のポテンシャルエネルギー $U^{\text {spring }}$ は, 次式で表現できる.

$$
U^{\text {spring }}=\sum_{i=2}^{m} \sum_{j=1}^{n} U_{i, j}^{\text {spring }}
$$

\section{3 糸の曲げ変形のモデリング}

次に, 系の曲げ変形を定式化する。ここで, 編み目の任意の 点における曲げモーメントが，その点における系の曲率の自然 状態からの変化分に比例すると仮定する。このとき，第 $(i, j)$ 編 み目の曲げによる弾性エネルギー $U_{i, j}^{\text {bend }}$ は次式で与えられる.

$$
U_{i, j}^{b e n d}=\int_{0}^{L} \frac{1}{2} R_{f}\left(\frac{d \theta_{i, j}(s)}{d s}-\frac{d \theta_{i, j}^{0}(s)}{d s}\right)^{2} d s
$$

ここで, $\theta_{i, j}^{0}(s)$ は自然状態における角度 $\theta_{i, j}(s)$ である。また, $R_{f}$ は, 系の曲げ剛性である. 全編み目の曲げの弾性エネルギー $U^{\text {bend }}$ は, 次式で表現できる.

$$
U^{\text {bend }}=\sum_{i=1}^{m} \sum_{j=1}^{n} U_{i, j}^{b e n d}
$$

全編み目のポテンシャルエネルギー $U$ は, 絡み部におけるバ ネのポテンシャルエネルギーと糸の曲げによる弾性エネルギー の和であると仮定する．すなわち，

$$
U=U^{\text {spring }}+U^{\text {bend }} \text {. }
$$

編み地の形状は, 系の曲げ変形のポテンシャルエネルギーと, 糸の絡まり部分のポテンシャルエネルギーとの比によって定ま る. したがって, 編み地の変形形状は, 曲げ剛性 $R_{f}$ の值なら びにバネ定数 $k_{a}, k_{b}$ の值に強く影響される.

ニットには，様々な位置拘束と力拘束が与えられる．これら の制約のもとで，ポテンシャルエネルギー $U$ が最小になる関 数 $\theta_{i, j}(s)(i=1,2, \cdots, m, j=1,2, \cdots, n)$ を求めることによ り, ニットの変形形状を求めることができる.

\section{4. 代表編み目法による変形形状の計算}

\section{1 モデルパラメータ}

編み地の変形形状を求めるためには,おのおのの編み目の変 形を計算しなくてはならない. 線状物体の变形形状を計算する 手法として, パラメータ化と最適化を用いる手法が提案されて いる [6]. 本論文では, 編み地の変形形状の計算に, この手法を 用いる。まず，関数 $\theta_{i, j}(s)$ を基底関数 $\phi_{1}(s), \cdots, \phi_{n_{b}}(s)$ の 線形和で表す。

$$
\theta_{i, j}(s) \triangleq \sum_{k=0}^{n_{b}} a_{i, j}^{k} \phi_{k}(s)=\boldsymbol{a}_{i, j}^{T} \boldsymbol{\phi}
$$

ここで, $\phi=\left[\phi_{1}, \phi_{2}, \cdots, \phi_{n_{b}}\right]^{T}$ は, 基底関数べクトルであり, $\boldsymbol{a}_{i, j}=\left[a_{i, j}^{1}, a_{i, j}^{2}, \cdots, a_{i, j}^{n_{b}}\right]^{T}$ は第 $(i, j)$ 編み目の $\boldsymbol{\phi}$ に対する係 数ベクトルである. 式（13）を式（12）に代入すると, ポテン シャルエネルギー $U$ は, 係数ベクトル $a_{i, j}(i=1, \cdots, m ; j=$ $1, \cdots, n)$ と第 $(i, 1)$ 編み目の左端の空間座標値 $x_{i}^{0}$ および $y_{i}^{0} \quad(i=1, \cdots, m)$ の関数となる.つまり, ポテンシャルエネ ルギー $U$ を与えられた拘束条件の下で最小とするような, 係 数べクトル $a_{i, j}$ および座標値 $x_{i}^{0}, y_{i}^{0}$ を求めることで, 全編 み目の变形形状が計算できる。本論文では, ベクトル $\boldsymbol{a}_{i, j}$ およ び $\phi_{i, j}$ をそれぞれ，編み目パラメー夕，編み目関数と呼ぶ.

編み地のモデルに必要なパラメータの数は，一般に大きくな る。例えば，編み地のサイズが $10 \times 10$ であり，編み目関数が 8 個の場合, 編み目パラメー夕は 800 個, 各 course の左端座標値 は 20 個あり，結局モデルパラメータは 820 個となる．モデル パラメータの数が多くなると, 変形形状の計算に膨大な時間を 要し，実際には計算ができないという場合が生じる。したがっ て，モデルパラメータの数は，できる限り減らす必要がある.

一般に，隣り合う編み目を観察すると，編み目の形状は似て いる場合が多い.したがって，いくつかの代表的な編み目を選び 出し, それ以外の編み目の形状は, 代表的な編み目の形状の近 似で表すことができると考えられる．力や変位を布地に与える 点, すなわち作用点の近傍では, 編み目の形状が大きく変化す る.このような作用点近傍に対しては, 代表となる編み目を多 く割り当てることにより，モデルの精度を確保することができ ると期待される，逆に，編み目の形状があまり変化しない箇所， 例えば作用点から離れたところでは，代表的な編み目の割り当 てを減らすことができる. 特に, wale 方向, course 方向の一様 
な変形に対しては，一つの代表的な編み目で編み地の変形を表 現することが可能である．以上のように，いくつかの代表的な 編み目の形状により, 編み地全体の変形形状を表す手法を, 代 表編み目法と呼ぶ。また，代表編み目法で用いる，他の編み目の 形状を表現するための代表的な編み目のことを，本論文では代 表編み目と呼ぶ，代表編み目法では，代表編み目をどのように 選ぶかが重要である。代表編み目を布地上のどこに設定するか は, モデルに要求される精度や, 対象とする作業に依存する.

\section{2 内㨂を用いた編み目形状の計算}

本節では, 代表編み目法の一例として, 内挿で編み目パラメー 夕を近似する手法を提案する。編み目関数 $\phi(s)$ および 編み目 パラメータ $\boldsymbol{a}_{i, j}$ は，それぞれ次式で与えられているとする.

$$
\begin{aligned}
\phi(s)= & {\left[\sin \frac{2 \pi}{L} s, \cdots, \sin \frac{2 \pi}{L} t s, \cos \frac{2 \pi}{L} s, \cdots, \cos \frac{2 \pi}{L} t s,\right.} \\
& s, 1]^{T} \in R^{2 t+2} \\
a_{i, j}= & {\left[a_{i, j}^{1}, a_{i, j}^{2}, \cdots, a_{i, j}^{2 t+2}\right]^{T} \in R^{2 t+2} }
\end{aligned}
$$

編み目形状ならびにその曲率の連続性を考慮すると, 編み目パ ラメータは独立ではない，以下，編み目パラメー夕間の関係を 調べる.ここで, 第 $(i, j)$ 編み目の 部分編み目パラメー夕 $\hat{\boldsymbol{a}}_{i, j}$ を次式で定義する.

$$
\hat{\boldsymbol{a}}_{i, j} \triangleq\left[a_{i, j}^{1}, a_{i, j}^{2}, \cdots, a_{i, j}^{2 t}\right]^{T} \in R^{2 t}
$$

第 $(i, j)$ 編み目の右端と, 第 $(i, j+1)$ 編み目の左端において, 角度と曲率が一致しなければならない。したがって，第 $(i, j)$ 編み目㧍よび第 $(i, j+1)$ 編み目 $(i=1, \cdots, m ; j=1, \cdots, n)$ は，次式で表される境界条件を満たさなければならない。

$$
\begin{aligned}
\theta_{i, j}(L) & =\theta_{i, j+1}(0), \\
\frac{d \theta_{i, j}(L)}{d s} & =\frac{d \theta_{i, j+1}(0)}{d s}
\end{aligned}
$$

式（14）を式（17）に代入し，次式を得る.

$$
\begin{aligned}
a_{i, j+1}^{2 t+2}= & {[0,0, \cdots, 0,1,1, \cdots, 1]\left(\hat{\boldsymbol{a}}_{i, j}-\hat{\boldsymbol{a}}_{i, j+1}\right) } \\
& +a_{i, j}^{2 t+1} L+a_{i, j}^{2 t+2}
\end{aligned}
$$

式（14）を式（18）に代入し，次式を得る.

$$
\begin{aligned}
a_{i, j+1}^{2 t+1}= & \frac{2 \pi}{L}[1,2, \cdots, t, 0,0, \cdots, 0]\left(\hat{\boldsymbol{a}}_{i, j}-\hat{\boldsymbol{a}}_{i, j+1}\right) \\
& +a_{i, j}^{2 t+1}
\end{aligned}
$$

編み目パラメータ間には式 (19)，（20）で与えられる制約があ る.したがって, 部分編み目パラメータ $\hat{\boldsymbol{a}}_{i, j}(i=1, \cdots, m, j=$ $1, \cdots, n)$ と編み目パラメータの一部 $a_{i, 1}^{2 t+1}$ および $a_{i, 1}^{2 t+2}$ が既知 であれば, 式 (19)，(20)を用いることにより, 残りの編み目パラ メー夕 $a_{i, j}^{2 t+1}$ および $a_{i, j}^{2 t+2}(i=1,2, \cdots, m ; j=2,3, \cdots, n)$ を計算できる．このとき，境界条件 式（17）および（18）は自 動的に満たされる。

ここで，隣り合う編み目の形状が急激に変化しないことに 着目し, 部分編み目パラメー夕を, ある代表的な編み目の編 み目パラメータの内挿で近似的に表現することによって，モ デルの計算時間を削減する手法を提案する，まず，布地を長方 形の領域に分割し，その 4 隅に代表編み目を設定する。そし

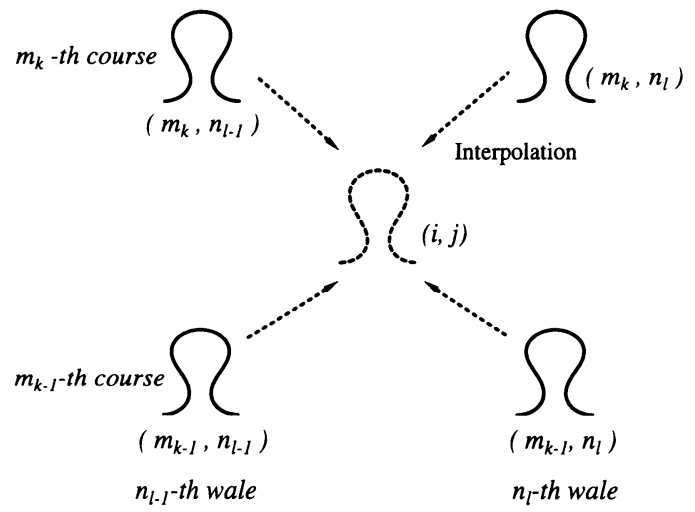

Fig. 8 Interpolation of loop parameters

て, Fig. 8 に示すように，その長方形の内部の編み目形状を, 4 隅の代表編み目の形状を用いて表現する。 ニットの編み目が， wale, course のように縦横へ配列されているため, 長方形分割 が妥当である。いま，代表編み目となる編み目の数が，wale， courseに沿ってそれぞれ, $p, q$ 個であり，合計として $p \times q$ 個 あるとする．このとき，Fig. 8 に示すように，代表編み目は， $\boldsymbol{a}_{m_{k}, n_{l}}(k=1,2, \cdots, p ; l=1,2, \cdots, q)$ で表されるとする.た だし， $m_{1}=n_{1}=1, m_{p}=m, n_{q}=n$ である.つまり，布 の 4 隅は, 必ず代表編み目とする。ここで, 第 $\left(m_{k}, 1\right)$ 編み目 $(k=1,2, \cdots, p)$ における編み目パラメータ $\boldsymbol{a}_{m_{k}, 1}$ ならびに第 $\left(m_{k}, n_{l}\right)$ 編み目 $(k=1,2, \cdots, p ; l=2,3, \cdots, q)$ に扔ける部 分編み目パラメー夕 $\hat{\boldsymbol{a}}_{m_{k}, n_{l}}$ を, 代表編み目パラメータと定義 する。代表編み目以外の編み目パラメー夕 $\boldsymbol{a}_{i, j}$ は，すべて代 表編み目パラメータから計算することができる。この手法を用 いると，モデルパラメータの数が削減される. 例えば, 編み地 が $10 \times 10$ であり，編み目関数の数が 8 の場合に 4 隅のみに代 表編み目を設定すると，代表編み目パラメー夕の数と各 course の左端座標値の数の和は 48 個となり, 当初の 820 個と比較し て，パラメータの数が減少していることが分かる．これによっ て, 計算時間が削減されると考えられる.

部分編み目パラメータ $\hat{\boldsymbol{a}}_{i, j}$ は, 代表編み目の部分編み目パ ラメータ $\hat{\boldsymbol{a}}_{m_{k-1}, n_{l-1}}, \hat{\boldsymbol{a}}_{m_{k-1}, n_{l}}, \hat{\boldsymbol{a}}_{m_{k}, n_{l-1}}$ および $\hat{\boldsymbol{a}}_{m_{k}, n_{l}}$ の 内挿によって，次式のように表されると仮定する.

$$
\begin{aligned}
\hat{\boldsymbol{a}}_{i, j}= & \left(1-\lambda_{k, i}\right)\left(1-\mu_{l, j}\right) \hat{\boldsymbol{a}}_{m_{k-1}, n_{l-1}} \\
& +\left(1-\lambda_{k, i}\right) \mu_{l, j} \hat{\boldsymbol{a}}_{m_{k-1}, n_{l}}+\lambda_{k, i}\left(1-\mu_{l, j}\right) \hat{\boldsymbol{a}}_{m_{k}, n_{l-1}} \\
& +\lambda_{k, i} \mu_{l, j} \hat{\boldsymbol{a}}_{m_{k}, n_{l}} \\
\lambda_{k, i} \triangleq & \frac{i-m_{k-1}}{m_{k}-m_{k-1}}, \quad \mu_{l, j} \triangleq \frac{j-n_{l-1}}{n_{l}-n_{l-1}}
\end{aligned}
$$

ただし， $k, l$ はそれぞれ， $k-1<i \leq k$ および $l-1<j \leq l$ を満たす整数である。式 (21) は, 領域の 4 隅の代表編み目パ ラメータから領域内部の部分編み目パラメータを求める, 線形 補間式を, 式 (22) は，その補間の係数を表す。隣り合う編み 目の形状が急激に变化せず, 次第に変化していく場合には上式 は妥当であると考える。また, 編み地の左端の編み目は次式を 满たすように決定する。 


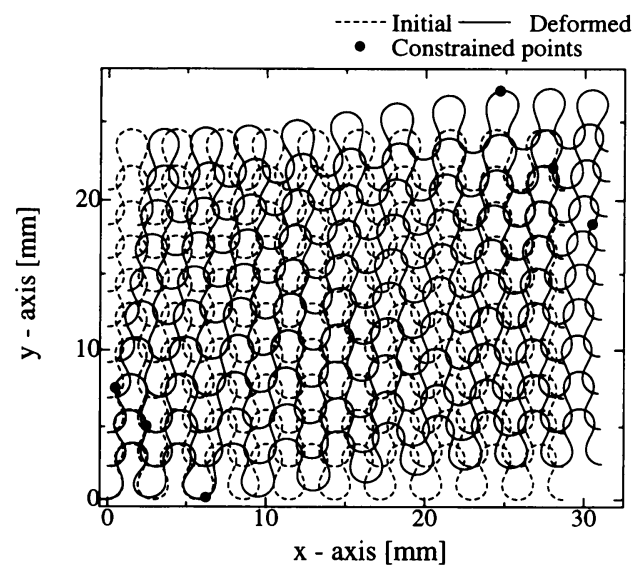

Fig. 9 Calculated shapes

$$
\boldsymbol{a}_{i, 1}=\left(1-\lambda_{k, i}\right) \boldsymbol{a}_{m_{k-1}, 1}+\lambda_{k, i} \boldsymbol{a}_{m_{k}, 1}
$$

式（21）および式（23）を用いることにより, 式（19）および 式 (20) が計算できる。つまり, 式 (19)，（20）および式 (21) より,すべての編み目パラメータは代表編み目パラメータから 計算することができる.つまり，代表編み目パラメータおよび 各 course の左端座標を用いて, 式 (12) で表される編み地の ポテンシャルエネルギー $U$ を表現することができる.

内挿を使った代表編み目法の有効性を確認するために, 布地 全体の 4 隅のみを代表編み目に設定する. 編み地を斜め方向へ 引っ張った場合の変形形状の計算結果を, Fig. 9 に示す.ただ し, 絡まり部分におけるバネ定数および糸の曲げ剛性はそれぞ れ, $k_{a}=1.0, k_{b}=0.01$ および $R_{f}=1.0$ である.ここで, $k_{a}, k_{b}$, および $R_{f}$ の值は, 第 5 節の実験結果で用いる布地と 同じものを想定した．簡単のため, wale, courseへの引っ張り 実験を行い, その両方の結果が実験とよく一致するような係数 を試行錯誤によって求めた. 幾何学的拘束条件として次式を与 えている.

$$
\begin{array}{lll}
x_{3,1}(3.6)=0.46, & y_{3,1}(3.6)=7.5 \\
x_{2,1}(6.7)=2.4, & y_{2,1}(6.7)=5.0 \\
x_{1,3}(0.5)=6.2, & y_{1,3}(0.5)=0.13, \\
x_{10,8}(4.9)=25, & y_{10,8}(4.9)=27 \\
x_{9,9}(8.1)=28, & y_{9,9}(8.1)=22, \\
x_{7,10}(7.6)=30, & y_{7,10}(7.6)=18
\end{array}
$$

この拘束は, 第 5 節の Fig. 12 に示すように, 布の左下端と, 右 上端を斜めにクランプし, 左下端を固定し, 右上端を右上へ引っ 張る状況を表している。計算に要した時間は，CPUにDEC Alpha 21164 (433[MHz]) を使用して, $65.9[\mathrm{~h}]$ であった.

\section{3 均一な編み目形状の計算}

前節では, 代表編み目の内挿によって他の編み目形状を表現 する方法を提案した。本節では, ある範囲において, 編み目の 変形形状が wale 方向もしくは course 方向に均一である場合を 扱う。この場合, 編み地の変形形状が一つの編み目の形状を縦 横へ繰り返したものであると考えられる。 そこで,一つの代表 編み目の形状を用いてすべての形状を決定する手法を提案す る.この手法では, モデルパラメータの数が, 一つの編み目パ

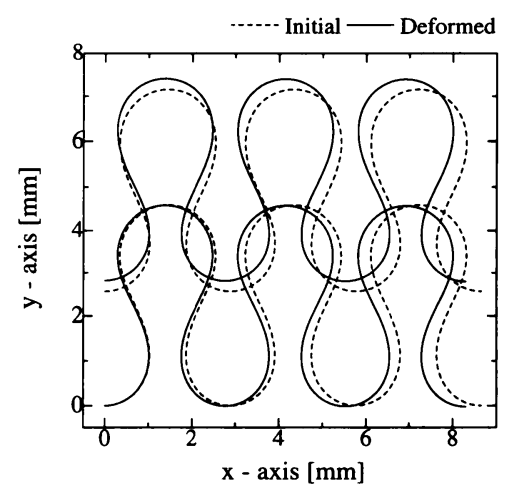

Fig. 10 Calculated shape of walewise deformation

ラメータのみになるため, 計算時間削減の効果が大きい. 例え ば, 編み目関数の個数が 8 個の場合, 編み目パラメータの数が 8 個と, 編み目の左端座標値の $y$ 軸方向への距離一つが変数と なり, 合計 9 個がモデルパラメータの数となる. 当初の 820 個 と比較して分かるように，パラメータの数が非常に削減されて いる.さらに，このような均一な変形を扱う作業も実際に多く 存在するため, 本手法の必要性は高い.

変形が wale 方向または course 方向へ均一であることは次式 で定式化される.

$$
\begin{aligned}
& \theta_{i, j}(s)=\theta_{1,1}(s) \quad \forall i, j \\
& x_{i}^{0}=x_{1}^{0}=0 \quad \forall i, j \\
& y_{i+1}^{0}-y_{i}^{0}=y_{2}^{0}-y_{1}^{0}=\alpha
\end{aligned}
$$

Wale 方向への一様な变形を計算する場合, $\alpha$ を与え, wale 方 向への変形量を定める. したがって, モデル中での変数は, $\theta_{1,1}$ である.さらに，次式を幾何学的拘束として与える.

$$
\begin{aligned}
& \theta_{1,1}(0)=\theta_{1,1}(L)=0 \\
& x_{1,1}(0)=y_{1,1}(0)=y_{1,1}(L)=0
\end{aligned}
$$

一方, course 方向への一様な変形を計算する場合, $\theta_{1,1}(s)$ およ び $y_{2}^{0}-y_{1}^{0}=\alpha$ が变数となる. また, 次式の拘束条件を与える.

$$
\begin{aligned}
& \theta_{1,1}(0)=\theta_{1,1}(L)=0 \\
& x_{1,1}(0)=y_{1,1}(0)=y_{1,1}(L)=0 \\
& x_{1,1}(L)=C_{w}
\end{aligned}
$$

ここで, $C_{w}$ は一つの編み目の course 方向の幅を表す.

Wale 方向および course 方向への変形形状の計算結果を, そ れぞれ Fig. 10 およびFig. 11 に示す.ここで, バネ定数およ び曲げ剛性は，それぞれ $k_{a}=1.0, k_{b}=0.01$, および $R_{f}=1.0$ である. 初期状態における $\alpha$ の值を $\alpha^{0}$ とおく. Fig. 10 の計 算例では， $\alpha=1.1 \alpha_{0}$ とおいてある．初期状態における $C_{w}$ を $C_{w}^{0}$ とおく. Fig. 11 の例では， $C_{w}=1.1 C_{w}^{0}$ である．計算に 要した時間は, CPUにDEC Alpha $21164(433[\mathrm{MHz}])$ を用 いて, Fig. 10 の場合, 1.36 [sec], Fig. 11 の場合, 0.35 [sec] で あった。

\section{5. 実 験 結 果}

提案したモデルの有効性を示すために，モデルを用いた計算 結果と実際の布地の変形形状を比較する. 


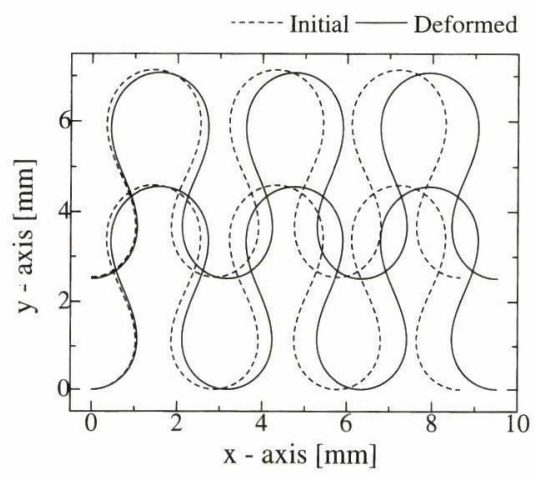

Fig. 11 Calculated shape of coursewise deformation

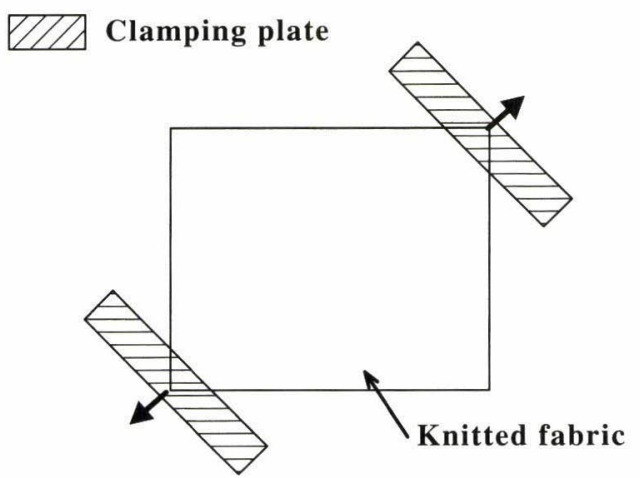

Fig. 12 Experimental condition in non-uniform deformation

編み地を斜め方向へ引つ張った場合の様子を, Fig. 12 に示 す. 図に示すように，布の頂点を約 $45[\mathrm{deg}]$ の角度でクランプ し，前節の計算例で与えた拘束式 $(24)$ を実現するように，左 下端のクランプ部を固定し，右上端部を右上へ引っ張った。使 用した布地は綿製の平編み地であり, サイズは，無負荷状態で， 約 $33[\mathrm{~mm}] \times 28[\mathrm{~mm}]$ である。また，布地の変形を観察するた めの CCD カメラは，撮影する画像中に布地がすべて入るよう に設置した．撮像範囲は, $39[\mathrm{~mm}] \times 34[\mathrm{~mm}]$ である.

斜め方向へ引っ張った場合の変形形状のモデルによる計算結 果をFig. 13 に示す。この図を見て分かるように, クランプし た箇所に近い部分では, 比較的計算結果と実際の变形が一致し ている、しかしながら, クランプから離れた部分では, 計算結 果と実際の変形があまり一致していない。このことは, 布地の 四隅に代表編み目を設定したため, クランプ部の影響が，クラ ンプした箇所から遠い部分まで，内挿によって伝達されたこと が原因の一つであると考えられる。このような現象は，代表編 み目を適切に設定することで, 解決できると考えられる.

Wale 方向および course 方向へ引つ張った場合の様子を, Fig. 14 に示す。使用した布地は斜めに引っ張った場合と同種 の平編み地であり, サイズは無負荷状態で, $60[\mathrm{~mm}] \times 60[\mathrm{~mm}]$ である、また，両端より $10[\mathrm{~mm}]$ 程度の幅をクランプし, 変位 を与えた. Wale 方向への変形の場合, カメラで撮影している 画像中の編み目間の距離 $\alpha$ が初期状態の距離の 1.1 倍になるよ うに, クランプ部を引っ張った. 同様に, course 方向への変形

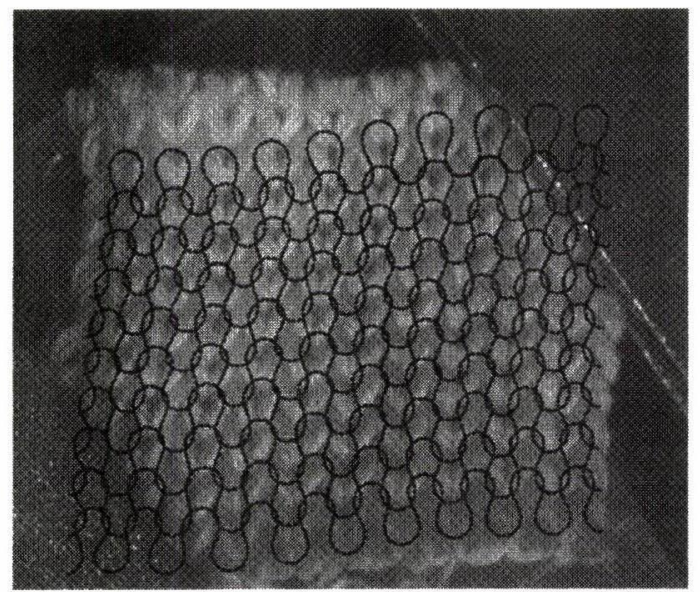

Fig. 13 Computed shape superimposed on CCD image

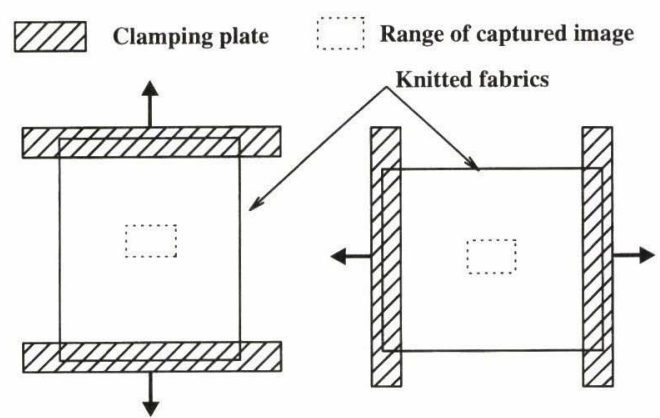

(i) Walewise

(ii) Coursewise

Fig. 14 Experimental condition in uniform deformation

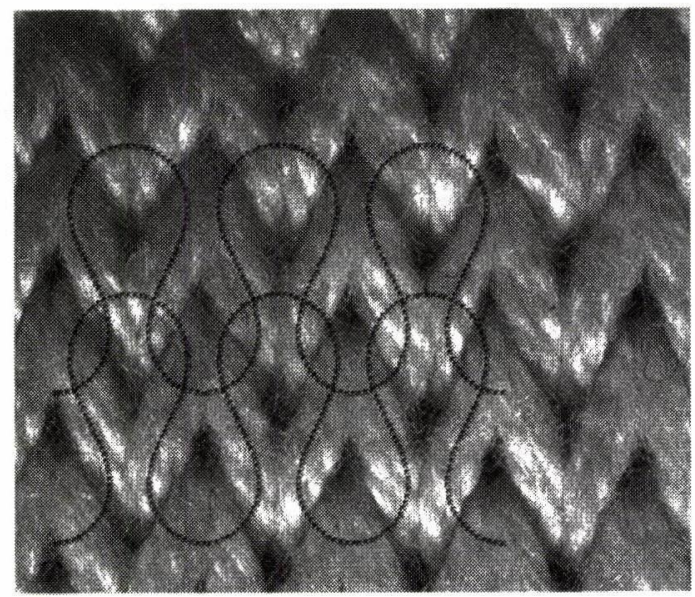

Fig. 15 Computed walewise deformed shape superimposed on CCD image

の場合は，上述の距離 $C_{w}$ が初期状態の距離の 1.1 倍になる ように,クランプ部を引っ張った。ただし，布地の変形を観察 するための CCD カメラは，布地のほぼ中央に設置した。撮像 範囲は, wale 方向の場合, $11[\mathrm{~mm}] \times 12[\mathrm{~mm}]$, course 方向の 場合, $13[\mathrm{~mm}] \times 15[\mathrm{~mm}]$ である.

Wale 方向および course 方向へ引っ張った変形形状の計算結 


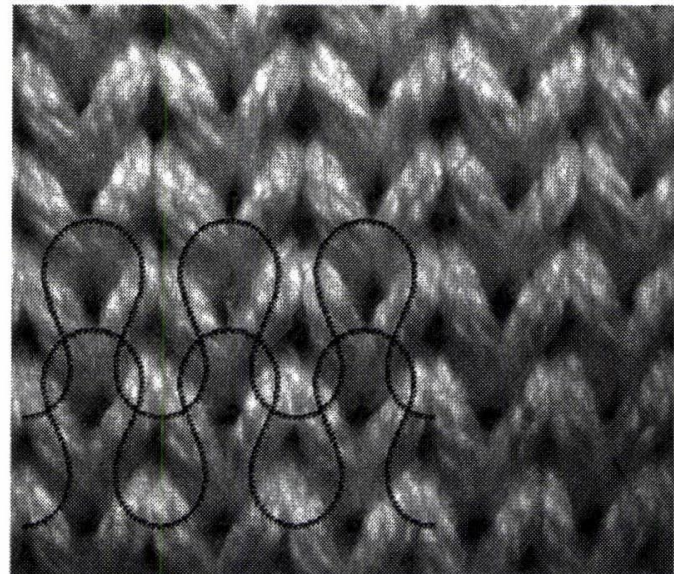

Fig. 16 Computed coursewise deformed shape superimposed on CCD image

果を, 編み地の変形形状を CCD カメラからの画像に重ね合わ せた結果をそれぞれ，Fig. 15 およびFig. 16 に示す.これら の図を見て分かるように, 計算結果が, 実際の系のほぼ中心を 通っていることが確認できる。これにより, 均一な引っ張りを 行う場合には, 本モデルおよび計算手法が, 編み目の変形形状 を表現するための手段として有効であることが分かる.

\section{6. おわりに}

本論文では，ニット製品の製造工程自動化を目的として，編み 目の位置および変形形状が記述できるニットの数理モデルを提案 した，さらに，モデルの計算時間を短縮するために，代表編み目 法を提案した. 代表編み目法としては，1）一般の変形に適用可 能な, 内插補間を用いる計算手法, および，2）均一な変形
を記述可能な計算手法，を提案し，実験によりその有効性を確 認した。実際の布地の変形との比較から斜め方向への引っ張り に対しては, クランプした部分に近い部分では, 計算結果と実 際の変形形状が比較的よく一致することが分かった。また，均 一な変形の場合は，ほぼ計算結果と実際の変形が一致している ことを確認し，モデルの有効性を示した。

不均一な変形を記述する際に, 代表編み目法を用いた場合, 急激な変形を記述することができない。これは, 編み目パラ メータの補間の性質による限界であると考えられる。この問題 は, 代表編み目を適切に増やすことにより, 解決できる。 そこ で, 変形の種類に応じて, 適切な代表編み目を決定する手法を 確立することが今後の課題として挙げられる。 また，系の曲げ 剛性 $R_{f}$ と絡まり部分でのバネ剛性 $k_{a}, k_{b}$ の系統的な同定方 法も, 今後の課題の一つである. さらに, 提案するモデルを用 いて, 制御戦略を提案することも今後の重要な課題である.

\section{参 考 文 献}

[1] B.G.A.V. Leaf: "Models of the Plain-Knitted Loop," Journal of the Textile Institute Transactions, vol.51, no.2, pp.49-58, 1960.

[2] 川端他： “平編布（平編地）の二軸伸長特性に関する理論的研究, 第 1 報 理論”, 日本繊維機械学会論文集, vol.23, no.5, pp.95-108, 1970.

[3] J. Weil : "The synthesis of Cloth Objects," Computer Graphics, vol.20, no.4, pp.49-54, 1986.

[4] D. Terzopoulos, et al. : "Elastically Deformable Models," Computer Graphics, vol.21, no.4, pp.205-214, 1987.

[5] センイ・ジヤアナル編：ニット素材・縫製ブック.pp.53-61, センイ・ ジヤァナル, 1994.

[6] S. Hirai, H. Wakamatsu and K. Iwata: "Modeling of Deformable Thin Parts for Their Manipulation," Proc. of IEEE Int. Conf. Robotics and Automation, pp.2955-2960, 1994.

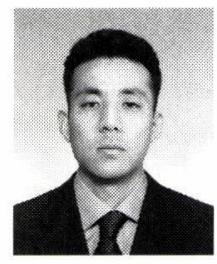

測自動制御学会, 日本繊維機械学会, 繊維学会, IEEE の学生会員。

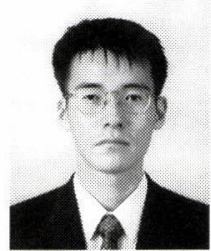
(日本ロボット学会学生会員)

和田隆広 (Takahiro Wada)

1971 年 8 月 3 日生. 1994 年立命館大学理工学部機 械工学科卒業. 1996 年同大学大学院理工学研究科 情報システム学専攻修士課程修了. 同年同大学理 工学研究科総合理工学専攻博士課程後期課程に入 学，現在に至る。ニット製品の自動生産など，柔軟 物体のマニピュレーションに関する研究に従事. 計

平野達也 (Tatsuya Hirano)

1972 年 11 月 29 日生. 1996 年立命館大学理工学 部機械工学科卒業. 同年より同大大学院博士課程 前期課程に在籍。（日本ロボット学会学生会員）

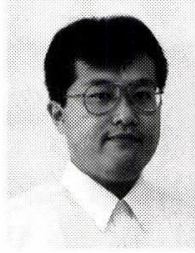

平井慎一 (Shinichi Hirai)

1963 年 3 月 19 日生. 1990 年京都大学大学院工学 研究科 博士課程数理工学専攻単位取得退学. 同年 大阪大学工学部電子制御機械工学科助手. 1995 年 同助教授. 1996 年立命館大学理工学部ロボティク ス学科助教授となり, 現在に至る。1990 年度計測 自動制御学会論文賞. 1996 年度日本機械学会ロボ ティクスメカトロニクス部門業績賞. 日本機械学会, 計測自動制御学 会, IEEE などの会員.

(日本ロボット学会正会員)

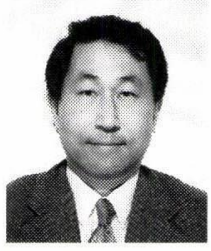

川村貞夫（Sadao Kawamura）

1956 年 7 月 10 日生. 1981 年大阪大学基礎工学部 生物工学科卒業. 1986 年同大学大学院博士課程修 了. 工学博士. 同年大阪大学基礎工学部助手. 1987 年立命館大学理工学部機械工学科助教授. 1995 年 同教授. 1996 年立命館大学理工学部ロボティクス 学科教授. 学習制御, ロボットの運動制御, 空気圧 駆動システム, ワイヤ駆動システム, 人間運動特性の計測・解析など の研究に従事. IEEE, システム制御情報学会, 日本機械学会, 計測 自動制御学会等の会員. 